Gerd Hentschel*

Carl von Ossietzky Universität Oldenburg (Niemcy)

(iD https://orcid.org/0000-0003-2034-1577

Istuán Fekete**1

Carl von Ossietzky Universität Oldenburg (Niemcy)

DOI: http://doi.org/10.31261/FL.2019.06.02

(D) https://orcid.org/0000-0002-6734-3660

Jolanta Tambor***

Uniwersytet Śląski $w$ Katowicach

(D) https://orcid.org/0000-0002-0801-3821

\title{
Głos $w$ sprawie aktualnego stanu użycia zapożyczeń niemieckich we współczesnym etnolekcie śląskim \\ i postaw językowych jego użytkowników (raport wstępny z projektu badawczego)
}

On the Use of German Loan Words in Silesians' Contemporary Ethnolect and Their Linguistic Attitudes

(a Working Paper from a Research Project)

Słowa klucze: etnolekt śląski, germanizmy, postawy językowe, subiektywna frekwencja, kodyfikacja

Key words: Silesian ethnolect, German loans, language attitudes, subjective frequency, codification

1. Tło

W ostatnich latach trwa w Polsce burzliwa i niepozbawiona emocji dyskusja na temat etnolektu śląskiego, a jej przedmiotem jest głównie kwestia prawnego uznania śląskiego za język regionalny. Dyskusja owa toczy się w środowisku naukowym, ale przede wszystkim $w$ przestrzeni medialnej. Wiele głosów - niestety - nie ma charakteru merytorycznego, wysuwane argumenty często pozbawione są podstawy naukowej, badawczej. Tym trudniej więc o rzeczowość i racjonalność opinii, ocen i postulatów.

Dzisiejsza śląszczyzna, dzisiejszy etnolekt² śląski jest współczesnym wariantem tego, co przez długi czas określano po niemiecku jako Wasserpolnisch. Termin ten - tłumaczony na

* e-mail: gerd.hentschel@uni-oldenburg.de

** e-mail: istuan.fekete1@uol.de

*** e-mail: jolanta.tambor@us.edu.pl

1 Istuán Fekete (niebędący slawistą) sprawdzał wszystkie analizy statystyczne, a bardziej skomplikowane obliczenia przeprowadzał sam.

${ }^{2}$ Termin etnolekt (wymiennie z: lekt) jest wobec temperatury owych dyskusji jedynym możliwym określeniem, które uznano za wystarczająco neutralne; wszystkie inne - śląszczyzna, gwara śląska, dialekt śląski, język śląski, mowa śląska itp. - są obciążone politycznie, społecznie, gdyż przez jedną ze stron sporu uznawane są za określenie pejoratywne lub za niedopuszczalne nadużycie. 
język polski jako „rozwodniona polszczyzna” - miał w XIX i XX wieku negatywną konotację, ponieważ oznaczał polszczyznę „rozwodnioną” słowami pochodzenia niemieckiego. Już Reinhold Olesch (jeden z czołowych slawistów swoich czasów, mający śląskie korzenie; zmarły w 1990 r.) wyjaśniał jednak, że - biorąc pod uwage podstawowe struktury śląski ma co prawda słowiański charakter, ale szczególnie w zakresie leksyki widoczny jest w nim bardzo wyraźny wpływ niemieckiego (OLESCH, 1978). I to właśnie ów silny wpływ niemieckiego na śląski jeszcze na długo przed apogeum zapożyczeń z niemieckiego do śląskiego skłonił Johanna Christopha Adelunga do pogardliwych i stygmatyzujących wypowiedzi (zob. np. Adelung, 1809: 670) o tym lekcie. Negatywne komentarze na temat „mieszanej gwary” (niem. gemischtes Idiom) można spotkać zarówno w niemieckich, jak i polskich publikacjach (por. obszerne dyskusje w: КосувA, 2015 і CZESAK, 2015). Te stwierdzenia przedostały się do opinii publicznej, wpłynęły na ocenę śląszczyzny przez Polaków i $w$ starszych pokoleniach pojawiają się do dziś.

Antonina Grybosıowa (1998) pisała, że po swojej przeprowadzce z Małopolski na Górny Śląsk (jako polonistka z wykształcenia i późniejsza profesor polonistyki na Uniwersytecie Śląskim w Katowicach) nie rozumiała wielu śląskich rozmów, głównie z powodu licznych germanizmów w sferze leksyki. Ponieważ po roku 1945 (a we wschodniej części Śląska już po I wojnie światowej) polski zajął miejsce (wcześniej zajmowane przez język niemiecki) języka standardowego (ogólnego), tzn. „języka dachu” (niem. Dachsprache) lub „odmiany wysokiej” (ang. high-variety) w „językowej architekturze” Górnego Śląska, etnolekt śląski najprawdopodobniej (znów, po latach wzmożonych niemieckich wpływów leksykalnych) zbliżył się pod względem leksykalnym do polszczyzny (przede wszystkim tej standardowej). Silny wpływ języków standardowych na stare dialekty i gwary w Europie jest dobrze znany, dlatego powstaje pytanie: Jak często jeszcze we współczesnym lekcie śląskim używane są niemieckie zapożyczenia? I to właśnie zagadnienie stanowi temat niniejszego artykułu i główny problem badawczy projektu³.

W stosunku do omawianego etnolektu nie można mówić o ogólnośląskich regularnościach jego użycia - nie ma i nie było ogólnośląskiego uzusu, nie wspominając już o wyraźnie sformułowanej normie, skodyfikowanej w słownikach i gramatykach. Poza tym nie ma wątpliwości, że $w$ śląskim rozwinęło się wiele tzw. miejskich koine, względnie dialektów (odmian) miejskich, ponieważ dzięki intensywnej migracji ludności ze wsi do miast, która była następstwem rozwoju przemysłu i idącej z nim w parze urbanizacji kolejnych obszarów Górnego Śląska, śląski - pierwotnie mający charakter wiejsko-gwarowy - wkroczył do miast. Obecnie trwają prace nad kodyfikacją śląskiego (por. TAmBor, 2009; Czesak, 2015; КосүвА, 2015), со oczywiście wywołuje wiele sporów. Należy dodać, iż w pracach kodyfikacyjnych $w$ większości biorą udział niejęzykoznawcy, amatorzy, fascynaci. Lingwiści nie uczestniczą nawet $w$ dyskusjach i nie podejmują się opiniowania kolejnych propozycji.

3 Projekt ten, noszący tytuł: Niemiecko-polskie ogólnojęzykowe paralelizmy leksykalne we współczesnym śląskim wariancie mówionym, finansowany jest przez Pełnomocniczkę ds. Kultury i Mediów (niem. Bundesbeauftragte für Kultur und Medien - BKM) w Bonn (Niemcy) Monikę Grütters, a kierowany - przez jednego z autorów niniejszego artykułu, Gerda Hentschela. Badania prowadzone są w kooperacji z Jolantą Tambor z Uniwersytetu Śląskiego w Katowicach i Jej zespołem. W tym miejscu kierownik projektu pragnie podziękować Kolegom z Katowic za współdziałanie i ogrom pracy włożonej $w$ to przedsięwzięcie. 
Głos w sprawie aktualnego stanu użycia zapożyczeń niemieckich...

A przynajmniej częściowa kodyfikacja byłaby konieczna - przy założeniu, że językowa edukacja śląska miałaby zostać wprowadzona do szkół, co przyczyniłoby się do stabilizacji i rewitalizacji etnolektu śląskiego. Przyznanie statusu języka regionalnego $w$ Polsce wiąże się z niewyrażonym wprost wymogiem kodyfikacji, przynajmniej w określonym stopniu lub określonym zakresie (por. na ten temat Hentschel, 2018).

Kolejną sporną kwestią, dotyczącą kodyfikacji śląskiego, jest włączenie do jego skodyfikowanej normy (lub do norm cząstkowych - w przypadku podjęcia decyzji o częściowej kodyfikacji obejmującej wybrane obszary Śląska) bądź wyłączenie z niej wielu niemieckich zapożyczeń. Nawet spora część zwolenników normatywizacji lektu śląskiego jako koniecznego etapu $w$ drodze do przyznania mu statusu języka regionalnego reprezentuje restrykcyjne stanowisko co do uwzględnienia germanizmów w tego typu kodyfikacji. Takie stanowisko jest motywowane również ogólnymi politycznymi argumentami. Zapewne akceptacja leksykalnej „mniej niemieckiej” (mniej obciążonej niemieckością) kodyfikacji - przez całe polskie społeczeństwo i na dodatek w obecnej, już i tak skomplikowanej, sytuacji politycznej w Polsce - mogłaby być (trochę) łatwiejsza. Należy sobie tylko zadać pytanie: Czy mówiący po śląsku sami zaakceptowaliby taką skodyfikowaną normę, pozbawioną części słownictwa, którym na co dzień się posługują? Żeby choć próbować na nie odpowiedzieć, trzeba by znać frekwencję pochodzących z niemieckiego tzw. śląskich ausdruków. W dotychczasowych pracach śląskoznawczych posługiwano się $w$ zasadzie wyłącznie szacunkami i mało naukowymi stwierdzeniami typu: wydaje się, należy sądzić itp., które są oparte na obserwacjach najbliższego otoczenia lub na jednostkowych wypowiedziach. Oczywiście, nikt nie neguje dziś wartości opisów tworzonych na podstawie „studiów przypadku”, jednak w omawianej kwestii niezbędne są szeroko zakrojone badania frekwencyjne, statystyczne, ilościowe i tylko one mogą zresztą obniżyć temperaturę emocjonalną dyskusji wokół śląszczyzny, a przede wszystkim wprowadzić do tej dyskusji rzeczowe argumenty. Badanie leksyki to wprawdzie dopiero początek drogi, ale ten pierwszy krok należy jak najszybciej wykonać.

To, czego dziś brakuje, to po pierwsze badania socjolingwistyczne, w których przedstawiano by dane na temat zakresu posługiwania się śląskim $w$ różnych częściach Górnego Śląska przez rdzenną ludność we wszystkich grupach wiekowych (z uwzględnieniem płci, różnych poziomów wykształcenia, grup zawodowych itd.) oraz postaw językowych i życzeń czy też oczekiwań wobec śląskiego lektu i germanizmów w śląskim. Po drugie, brakuje prac empirycznych pozwalających odpowiedzieć na pytanie: W jakim stopniu spora - z historycznego punktu widzenia - liczba germanizmów, jak dotąd kompleksowo nieopisanych, jest jeszcze w ogóle aktywnie używana przez rdzennych Ślązaków? Próba odpowiedzi na oba pytania stanowi kluczowy punkt zainteresowania autorów projektu i przedstawianego wstępnego raportu.

\section{Respondenci}

\subsection{Grupa docelowa}

2.1.1. Śląski i polski

Analiza skupia się na użytkownikach śląskiego, którzy w miarę regularnie, tj. dość często, mówią po śląsku. To kryterium wyboru respondentów jest $w$ projekcie decydujące. Pracow- 
nicy Instytutu Języka Polskiego, Katedry Międzynarodowych Studiów Polskich oraz Szkoły Języka i Kultury Polskiej Uniwersytetu Śląskiego w Katowicach wybierali ankietowanych zarówno ze swojego najbliższego otoczenia, jak i poprzez nawiązywanie kontaktów z oddziałami Związku Górnośląskiego, Ruchu Autonomii Śląska, parafiami, szkołami, klubami seniorów, domami kultury itp. Wybranym $w$ ten sposób respondentom zadano następnie pytanie dotyczące częstości używania przez nich zarówno śląskiego, jak i ogólnopolskiego. Tabela 1 ilustruje wyniki po przebadaniu prawie 500 respondentów, co stanowi 25\% całej zaplanowanej próby badawczej.

Tabela $1^{4}$

Jak często Pan/Pani mówi po śląsku / po polsku? (I) - odpowiedzi (wartości liczbowe)

\begin{tabular}{|c|c|c|c|c|c|c|c|}
\hline \multirow{2}{*}{\multicolumn{2}{|c|}{ Mówię... }} & \multicolumn{5}{|c|}{...po polsku } & \multirow{3}{*}{$\begin{array}{c}\text { R a ze m } \\
197\end{array}$} \\
\hline & & \multirow{2}{*}{$\begin{array}{c}\text { bardzo często } \\
82\end{array}$} & \multirow{2}{*}{$\begin{array}{r}\text { często } \\
73\end{array}$} & \multirow{2}{*}{$\begin{array}{c}\text { czasami } \\
32\end{array}$} & \multirow{2}{*}{$\begin{array}{c}\text { rzadko } \\
9\end{array}$} & \multirow{2}{*}{$\frac{\text { nigdy }}{1}$} & \\
\hline \multirow{5}{*}{...po śląsku } & bardzo często & & & & & & \\
\hline & często & 76 & 67 & 7 & 6 & 0 & 156 \\
\hline & czasami & 69 & 20 & 4 & 0 & 0 & 93 \\
\hline & rzadko & 27 & 4 & 0 & 0 & 0 & 31 \\
\hline & nigdy & 8 & 0 & 0 & 0 & 0 & 8 \\
\hline & Razem & 262 & 164 & 43 & 15 & 1 & 485 \\
\hline \multicolumn{2}{|c|}{13 - brak odpowiedzi } & & & & & & \\
\hline
\end{tabular}

39 respondentów, którzy podali informację, że po śląsku mówią rzadko lub w ogóle nie mówią, zostało wykluczonych z analizy, gdyż (zasadniczo) nie spełniają podstawowego kryterium przynależności do grupy docelowej. Wyłączono z dalszych badań również tych 4 respondentów, którzy zarówno $w$ stosunku do śląskiego, jak i polskiego stwierdzają, że obydwu „kodów” używają tylko czasami (można przypuszczać, iż znaczy to używanie obu lektów naprzemiennie, ale ankiety są anonimowe i nie dało się tej interpretacji zweryfikować), ponieważ ankietowanym postawiono jeszcze jeden wymóg: by jeden z tych dwu kodów (a nie np. niemiecki czy jeszcze inny język) był kodem dominującym. Poza tym 13 respondentów nie podało żadnej informacji na temat częstości użycia śląskiego i polskiego, co również wykluczyło te ankiety z kolejnych etapów projektu. Z podanych powodów, spośród początkowych 498 respondentów, dalszą analizą objęto 442 osoby.

Dla grupy tej częstotliwość używania śląskiego i (ogólnego) polskiego przedstawia się następująco (tab. 2):

Tabela 2

Jak często Pan/Pani mówi po śląsku / po polsku? (II) - odpowiedzi (wartości procentowe)

\begin{tabular}{|c|c|c|c|c|c|c|c|}
\hline \multirow{2}{*}{\multicolumn{2}{|c|}{ Mówię... }} & \multicolumn{5}{|c|}{...po polsku } & \multirow{3}{*}{$\begin{array}{r}\text { Raze m } \\
44,6\end{array}$} \\
\hline & & \multirow{2}{*}{$\begin{array}{c}\text { bardzo często } \\
18,6\end{array}$} & \multirow{2}{*}{$\begin{array}{c}\text { często } \\
16,5\end{array}$} & \multirow{2}{*}{$\begin{array}{c}\text { czasami } \\
7,2\end{array}$} & \multirow{2}{*}{$\begin{array}{c}\text { rzadko } \\
2,0\end{array}$} & \multirow{2}{*}{$\frac{\text { nigdy }}{0,2}$} & \\
\hline \multirow{3}{*}{...po śląsku } & bardzo często & & & & & & \\
\hline & często & 17,2 & 15,2 & 1,6 & 1,4 & $* * *$ & 35,3 \\
\hline & czasami & 15,6 & 4,5 & $* * *$ & $* * *$ & $* * *$ & 20,1 \\
\hline \multicolumn{2}{|r|}{ Razem } & 51,4 & 36,2 & 8,8 & 3,4 & 0,2 & 100,0 \\
\hline
\end{tabular}

${ }^{4}$ Wszystkie tabele, wykresy i schematy zostały opracowane przez autorów artykułu. 
Głos w sprawie aktualnego stanu użycia zapożyczeń niemieckich...

\subsubsection{Użycie niemieckiego}

Dla zbadanej dotąd grupy respondentów język niemiecki odgrywa - w najlepszym wypadku - marginalną rolę: 70\% z nich deklaruje, że nigdy go nie używa, a wyraźna większość spośród badanych (ponad 40\%) nawet go nie zna (por. tab. 3). Wpływ znajomości języka niemieckiego na wyniki badań może więc zostać pominięty $w$ dalszej analizie $w$ przedstawianym raporcie.

Jak często Pan/Pani mówi po niemiecku? - odpowiedzi

\begin{tabular}{|l|c|c|}
\hline \multicolumn{1}{|c|}{ Częstotliwość użycia } & $N$ & $\%$ \\
\hline Bardzo często & 1 & 0,2 \\
\hline Często & 7 & 1,7 \\
\hline Czasami & 27 & 6,4 \\
\hline Rzadko & 90 & 21,4 \\
\hline Nigdy, bo nie chcę lub nie mam okazji & 118 & 28,1 \\
\hline Nigdy, bo nie znam & 177 & 42,1 \\
\hline \multicolumn{2}{|r|}{ Razem } & 420 \\
\hline
\end{tabular}

"W tabeli uwzględniono tylko 420 spośród 442 wybranych do badań respondentów, ponieważ 22 nie podało żadnych danych na temat posługiwania się niemieckim lub jego znajomości, co jest informacją znaczącą, wymaga jednak osobnego opracowania.

\subsubsection{Tożsamość}

Kwestii tożsamości Ślązaków i określenia przez nich samych swojej przynależności do "Ślązaków”, „Polaków” i/lub „Niemców” sporo uwagi poświęciła Jolanta TAmBor (2008: 15-67). W naszej ankiecie poproszono respondentów o zaznaczenie, w jakim stopniu uważają się za „Ślązaka”, „Polaka” i „Niemca”. Mogli wybrać spośród odpowiedzi: tak - częściowo - nie. Oto uzyskane wyniki (tab. 4):

Tabela 4

Uważam się za... - odpowiedzi

\begin{tabular}{|c|c|c|c|c|c|c|}
\hline & \multicolumn{6}{|c|}{ Uważam się za... } \\
\hline & Ślązaka $[N]$ & Polaka $[N]$ & Niemca $[N]$ & Ślązaka [\%] & Polaka [\%] & Niemca [\%] \\
\hline Tak & 371 & 343 & 3 & 85,5 & 83,3 & 0,8 \\
\hline Częściowo & 60 & 60 & 31 & 13,8 & 14,6 & 8,4 \\
\hline $\mathrm{Nie}$ & 3 & 9 & 333 & 0,7 & 2,2 & 90,7 \\
\hline Razem & 434 & 412 & 367 & 100,0 & 100,0 & 100,0 \\
\hline Brakujące & 8 & 30 & 75 & & & \\
\hline Spośród & 442 & 442 & 442 & & & \\
\hline
\end{tabular}

Atrybuty „Ślązak” i „Polak” były wybierane jednakowo często, przez około 85\% jako wybór kategoryczny, a opcję częściowej identyfikacji zarówno śląskiej, jak i polskiej zaznaczyło prawie 15\% respondentów. (Na temat częściowego pokrywania się różnych tożsamości więcej w dalszej części opracowania). Niemal odwrotnie proporcjonalnie prezentują się dane dotyczące atrybutu „Niemiec” w określaniu tożsamości. Jednoznaczną odpowiedź „nie” wskazało 90\% ankietowanych, i tylko niespełna 10\% określiło swą identyfikację 
jako „częściowo” niemiecką. Nie sposób nie zauważyć dużych różnic liczbowych wśród brakujących odpowiedzi: spośród 442 respondentów brak tylko 8 zaznaczeń w wypadku atrybutu „Ślązak”, 30 - w wypadku atrybutu „Polak” i 75 - w wypadku atrybutu „Niemiec". Oczywiście, wykluczona jest tu szczegółowa interpretacja brakujących danych, jednak liczby wyraźnie pokazują, że ankietowani unikali pewnych odpowiedzi: na przykład „nie” w rubryce „Polak” oraz „tak” lub „częściowo” w rubryce „Niemiec”. To nie zmienia wszakże faktu, że śląska i/lub polska tożsamość jednoznacznie dominują i w znacznym stopniu się pokrywają (tab. 5):

Tabela 5

Uważam się za Ślązaka/Polaka - odpowiedzi

\begin{tabular}{|c|c|c|c|c|}
\hline Uważam się za... & \multicolumn{3}{|c|}{$\%\left(\begin{array}{ll}z & 407\end{array}\right)$} & \multirow[b]{2}{*}{$N$} \\
\hline Ślązaka Polaka & Tak & Częściowo & $\mathrm{Nie}$ & \\
\hline Tak & 72,0 & 10,6 & 2,0 & 344 \\
\hline Częściowo & 10,3 & 4,2 & 0,2 & 60 \\
\hline Nie & 0,7 & 0,0 & 0,0 & 3 \\
\hline Razem & & & & 407 \\
\hline
\end{tabular}

Wyniki są niepodważalne: ponad 3/4 respondentów w jednakowym stopniu czuje się jednocześnie Ślązakami i Polakami. To, czy wyrażają tę identyfikację za pomocą „tak”, czy "częściowo", w tabeli ilustrują wartości procentowe zapisane pogrubioną czcionką (różnica owa nie odgrywa żadnej roli). W przypadku 10 -procentowych wartości zaznaczonych $w$ tabeli kursywą jedna z tożsamości lekko dominuje nad drugą. Przedstawione wyniki dotyczą 95\% spośród 407 respondentów, którzy odpowiedzieli na obydwa pytania, i 90\% spośród ogółu ankietowanych, którzy określili swoją tożsamość jako śląską i polską.

\subsubsection{Pozostałe składniki socjodemograficznej charakterystyki respondentów}

498 dotychczas objętych badaniem respondentów stanowi 1/4 przyjętej $w$ projekcie liczby 2000 mówiących po śląsku (56 ankiet spośród nich zostało - co wyjaśniono - wykluczonych z dalszych etapów projektu). Przyjęty podział badanych wedle różnych kryteriów ma przede wszystkim na celu uwzględnienie $w$ mniej lub bardziej zrównoważony sposób zróżnicowania płci i wieku. Poza tym w pewnym zakresie powinny zostać wzięte pod uwagę różne regiony Śląska. Na potrzeby wstępnego raportu zamierzamy tylko pokrótce przybliżyć grupę wybranych respondentów.

Płeć

Spośród uwzględnionych dotąd $w$ analizie 442 ankietowanych 62\% stanowią kobiety, a 38\% mężczyźni. Obie płcie reprezentowane są w wystarczającym (nawet jeśli nierównym) zakresie.

\section{Wiek}

Tabela 6 ilustruje podział na 4 grupy wiekowe, począwszy od 18. roku życia (w wypadku najstarszej grupy wiekowej bez podania górnej granicy wieku): 
Głos $w$ sprawie aktualnego stanu użycia zapożyczeń niemieckich...

Tabela 6

Struktura wiekowa respondentów

\begin{tabular}{|l|c|c|c|}
\hline \multicolumn{1}{|c|}{ Urodzeni } & $N$ & $\%$ & $\begin{array}{c}\text { Skumulowane wartości } \\
\text { procentowe }\end{array}$ \\
\hline $1985-2001$ & 134 & 30,3 & 30,3 \\
\hline $1969-1984$ & 120 & 27,1 & 57,5 \\
\hline $1953-1968$ & 120 & 27,1 & 84,6 \\
\hline Przed $1953 \quad$ Razem & 442 & 15,4 & 100,0 \\
\hline
\end{tabular}

Podział respondentów na grupy wiekowe jest stosunkowo zrównoważony. Z przyczyn naturalnych mniejsza liczebność najstarszej grupy (65 lat i starsi) jest nie do uniknięcia (m.in. sama ankieta leksykalna jest bardzo czasochłonna i często osoby starsze nie chcą podejmować takiego wyzwania). Na potrzeby tej analizy liczba ankietowanych jest wszakże bardziej niż wystarczająca.

\section{Region}

Liczebność przyjętych grup w poszczególnych regionach $(N-$ zaplanowane) nie jest równomierna. Jej podstawę stanowi liczba mieszkańców i szacunki zespołu z Katowic dotyczące posługiwania się śląskim przez ludność w tych rejonach. Ponieważ brakuje dokładniejszych danych na temat używania śląskiego przez ludność Śląska w konkretnych podregionach (miastach, miasteczkach, wsiach), przedstawić możemy jedynie przybliżone dane szacunkowe (por. tab. 7).

Tabela 7

Liczba respondentów według regionów

\begin{tabular}{|c|c|c|c|c|}
\hline Region & $N$ - zaplanowane & $\%$ - zaplanowane & $N$ - objęte & $\%$ - objęte \\
\hline Opole & 200 & 10 & 1 & 0,2 \\
\hline Rybnik & 200 & 10 & 57 & 12,9 \\
\hline Wodzisław-Racibórz & 215 & 10,75 & 60 & 13,6 \\
\hline Katowice & 520 & 26 & 117 & 26,5 \\
\hline Bytom-Zabrze-Tarnowskie Góry & 380 & 19 & 97 & 21,9 \\
\hline Gliwice-Knurów-Pyskowice & 225 & 11,25 & 56 & 12,7 \\
\hline $\begin{array}{l}\text { Tychy-Mikołów/Orzesze/Łaziska } \\
\text { Górne - powiat pszczyński }\end{array}$ & 270 & 13,5 & 48 & 10,9 \\
\hline Razem & ok. 2000 & 100,0 & 436 & 98,6 \\
\hline Brakujące & & & 6 & 1,4 \\
\hline Ogółem & & & 442 & 100,0 \\
\hline
\end{tabular}

\section{Wykształcenie i zawód}

Ani poziom wykształcenia, ani zawód (por. tab. 8) nie były kryteriami decydującymi o wyborze respondentów. Oba atrybuty mają charakter informacji dodatkowych (choć nie możemy wykluczyć, że okażą się one $w$ rezultacie interesujące i znaczące). 
Gerd Hentschel, Istuán Fekete, Jolanta Tambor

Tabela 8

Wykształcenie respondentów

\begin{tabular}{|c|c|c|c|c|c|}
\hline Typ wykształcenia & $N$ & $\%$ & Poziom wykształcenia & $N$ & $\%$ \\
\hline podstawowe & 40 & 9,0 & \multirow{2}{*}{ podstawowy - zawodowy } & \multirow{2}{*}{96} & \multirow{2}{*}{21,7} \\
\hline zawodowe & 56 & 12,7 & & & \\
\hline średnie techniczne & 102 & 23,1 & \multirow{2}{*}{ średni } & \multirow{2}{*}{164} & \multirow{2}{*}{37,1} \\
\hline średnie ogólne & 62 & 14,0 & & & \\
\hline $\begin{array}{l}\text { wyższe } \\
\text { humanistyczno-społeczne }\end{array}$ & 98 & 22,2 & \multirow{2}{*}{ wyższy } & \multirow{2}{*}{167} & \multirow{2}{*}{37,8} \\
\hline $\begin{array}{l}\text { wyższe medyczne, ścisłe, } \\
\text { techniczne }\end{array}$ & 69 & 15,6 & & & \\
\hline inne & 14 & 3,2 & & & \\
\hline razem & 441 & 99,8 & razem & 427 & 96,6 \\
\hline brakujące & 1 & 0,2 & brakujące & 15 & 3,4 \\
\hline ogółem & 442 & 100,0 & ogółem & 442 & 100,0 \\
\hline
\end{tabular}

Dane dotyczące typów i poziomów wykształcenia są wystarczające $w$ takim stopniu, aby można było w toku dalszych badań poddać analizie statystycznej zmienną „typ wykształcenia”. Zmienną „poziom wykształcenia” przeanalizowano obecnie w sposób uproszczony, łącząc dwa pierwsze wskazania, a następnie trzecie i czwarte oraz piąte i szóste, co dało trójstopniową skalę (poziom podstawowy - zawodowy, średni oraz wyższy). Hipoteza dotycząca związku między częstotliwością posługiwania się śląskimi germanizmami a wykształceniem mówiącego po śląsku nie jest oczywista. W najlepszym wypadku można przyjąć, że im mówiący ma wyższe wykształcenie, tym większy wpływ na jego życie codzienne mogłaby mieć standardowa polszczyzna, a to pośrednio ograniczałoby używanie przez niego jakichkolwiek silezyzmów, zatem także takich o niemieckim pochodzeniu.

Zawody wykonywane przez respondentów, z uwzględnieniem uczniów i studentów, ilustruje tabela 9:

Tabela 9

Zawód (zajęcie) respondentów

\begin{tabular}{|c|c|c|}
\hline Typ zawodu (zajęcia) & $N$ & $\%$ \\
\hline Uczeń (szkoła zawodowa / technikum) & 7 & 1,6 \\
\hline Uczeń (liceum ogólnokształcące) & 29 & 6,6 \\
\hline Student (kierunki humanistyczno-społeczne) & 40 & 9,0 \\
\hline Student (kierunki medyczne, ścisłe, techniczne) & 5 & 1,1 \\
\hline Zawody medyczne & 33 & 7,5 \\
\hline Zawody pedagogiczne & 47 & 10,6 \\
\hline Zawody administracyjno-biurowe & 121 & 27,4 \\
\hline Zawody artystyczne & 3 & 0,7 \\
\hline Zawody związane z pracą fizyczną & 75 & 17,0 \\
\hline Policja/wojsko & 3 & 0,7 \\
\hline Inne & 64 & 14,5 \\
\hline Razem & 427 & 96,6 \\
\hline Brakujące & 15 & 3,4 \\
\hline O gó łe m & 442 & 100,0 \\
\hline
\end{tabular}


Głos w sprawie aktualnego stanu użycia zapożyczeń niemieckich...

Czy jest jakikolwiek związek między używaniem germanizmów i typem wykonywanego zawodu, trudno na razie rozstrzygnąć. Nasuwa się hipoteza, że wśród wykonawców zawodów fizycznych (rzemieślnicy, technicy itd.) używających lektu śląskiego tendencja do posługiwania się germanizmami może być silniejsza, gdyż nazwy narzędzi mają często niemiecką proweniencję. Można też przypuszczać, iż omawiane nazwy tkwią w ich języku bardziej trwale ze względu na możliwy zakres użycia lektu śląskiego, choć oczywiście ów zakres ma związek także z miejscem pracy, typem kontaktu zawodowego, pochodzeniem pozostałych pracowników itp. Niemniej jednak obu zmiennych (wykształcenia i zawodu) nie można $w$ badaniach pomijać, choć nie należy spodziewać się jednoznacznych wyników co do ścisłej ich relacji z frekwencją badanych leksemów.

\subsection{Postawy językowe $w$ stosunku do śląskiego}

W jednej ze swoich prac Gerd Hentschel (2018) podkreśla fakt, że w dotychczasowej dyskusji na temat śląskiego nie zwraca się uwagi na postawy i życzenia aktywnych użytkowników tego etnolektu wobec ich własnej „mowy”. Częściowo omówiła te zagadnienia Jolanta TАмвоR (2008), przytaczając wypowiedzi z rozmów i wywiadów. Są to jednak opinie jednostkowe, niepoparte badaniami frekwencyjnymi. Można z dużą dozą prawdopodobieństwa przypuszczać, że odzwierciedlają one stanowiska pewnych grup społecznych, ale tylko ankietowe badania prowadzone na dużej liczbie respondentów ( $w$ naszym projekcie: docelowo 2000 osób) z możliwym do opisu podziałem pokoleniowym i regionalnym pozwolą na uznanie ich za reprezentatywne. W przygotowanej na potrzeby projektu ankiecie socjodemograficznej zadano wiele pytań dotyczących obu kwestii. Reakcje ankietowanych na dziewięć szczególnie istotnych pytań zostaną omówione w dalszej części. Odpowiadając na pytania, respondenci musieli, korzystając z czterostopniowej skali, wyrazić swoją aprobatę lub dezaprobatę wobec przedstawionych treści. Niezdecydowanym pozostawiono również możliwość wyboru stosownej opinii.

\subsection{1. Śląski $w$ mediach i $w$ życiu publicznym}

Zamieszczone wykresy (1-5) ilustrują odpowiedzi ankietowanych na pytanie: Czy obecność śląskiego $w$ życiu publicznym powinna wzrosnąć?

Odpowiedzi respondentów na postawione pytanie, zilustrowane na wykresach, są bardzo podobne. Mówiący po śląsku zdecydowanie opowiadają się za większą obecnością śląskiego lektu w mediach i w szkole, są zwolennikami nauczania śląskiego lektu w szkołach. Odpowiedzi „raczej tak”, które rozumiemy jako ostrożnie wyrażoną aprobatę, są w każdym przypadku prawie dwukrotnie częstsze niż odpowiedzi „całkowicie”, oznaczające zdecydowane poparcie. Warto uwypuklić dwa wnioski z analizy danych. Po pierwsze, najczęstsze życzenie wyrażane przez ankietowanych dotyczy zwiększonej obecności śląskiego $w$ radiu i $w$ wariancie mówionym $w$ życiu publicznym ${ }^{6}$. Najrzadziej wśród ankietowych opinii pojawia się natomiast pragnienie większej obecności śląskiego $w$ prasie, czyli $w$ odmianie pisanej. Wszystkie te pojedyncze zmienne wskazują na istniejące między nimi ważne za-

\footnotetext{
${ }^{5}$ Na temat trudnych pytań: Czy śląski jest językiem czy dialektem? - por. Hentschel (2018).

${ }^{6}$ Chodzi tu o sklepy, restauracje, place publiczne, ulice itd., a nie o urzędy itp.
} 
leżności, które można zgeneralizować jako oczekiwanie wzrostu obecności śląskiego lektu w użyciach nieprywatnych wśród mówiących po śląsku?

Śląski powinien być bardziej obecny $w$ radiu - $w \%$

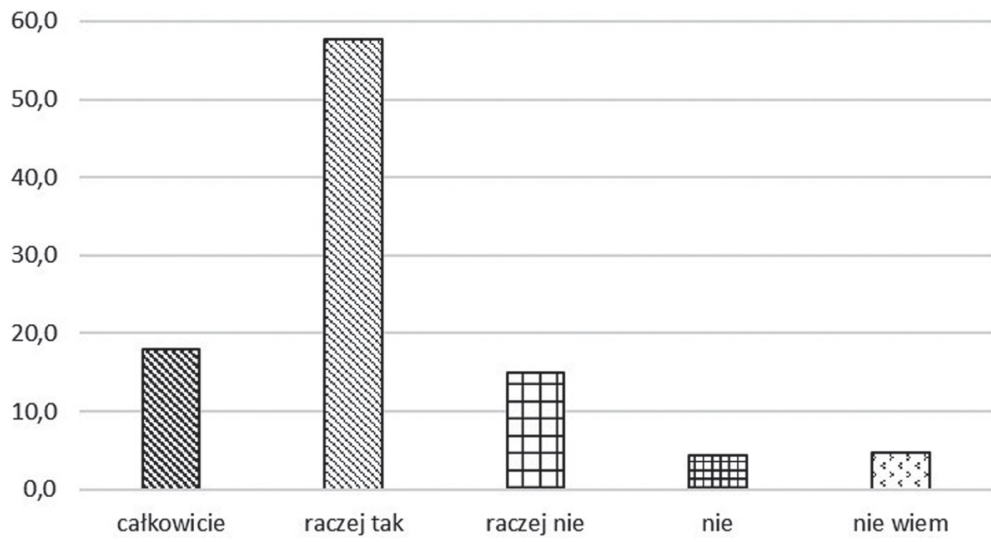

Śląski powinien być bardziej obecny $w$ telewizji - w \%

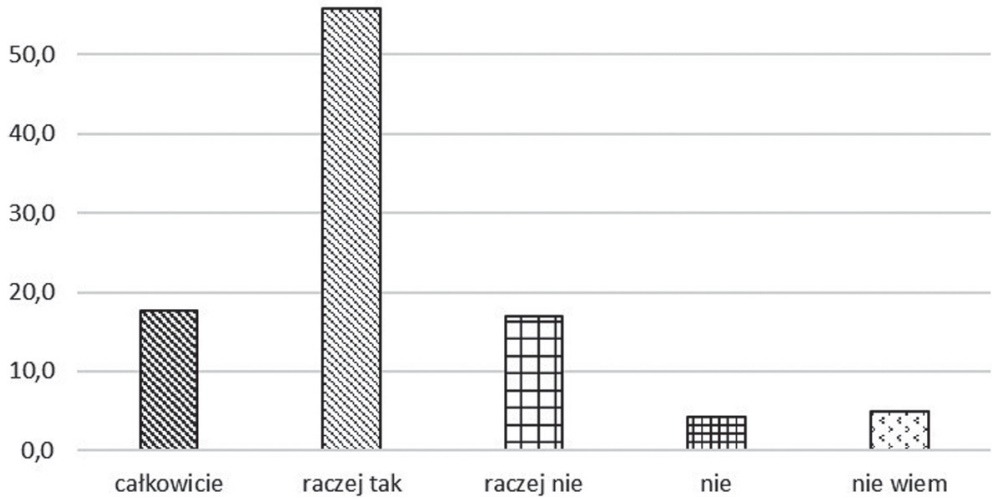

${ }^{7} \mathrm{~W}$ analizie czynnikowej dla tego „głównego składnika” ustalono następujące wysokie wartości korelacji: „Śląski powinien być bardziej obecny...” w radiu - 0,905, w telewizji - 0,905, w prasie 0,787, w urzędach - 0,660, w życiu publicznym - 0,552. To zagadnienie zostanie wyjaśnione w odrębnym artykule. 
Głos $w$ sprawie aktualnego stanu użycia zapożyczeń niemieckich...

Śląski powinien być bardziej obecny $w$ prasie - w \%

60,0

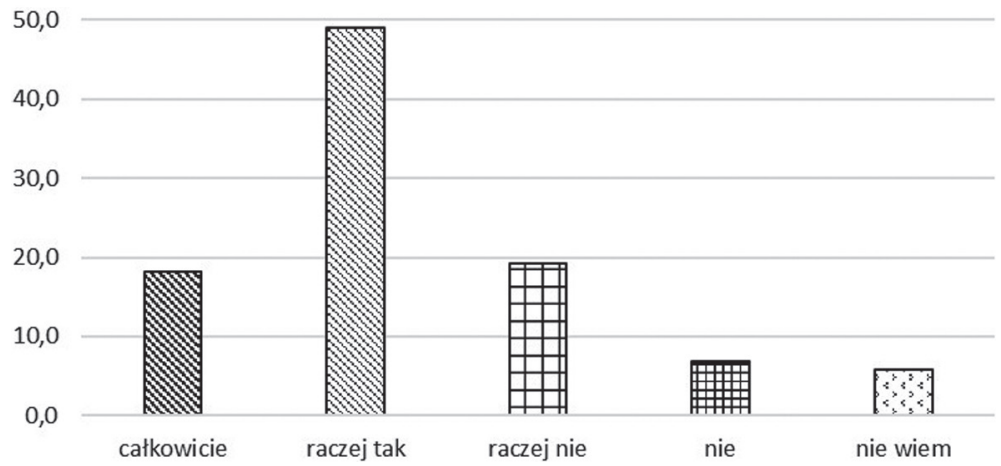

Śląski powinien być częściej używany w życiu publicznym - w \%

Wykres 4 60,0

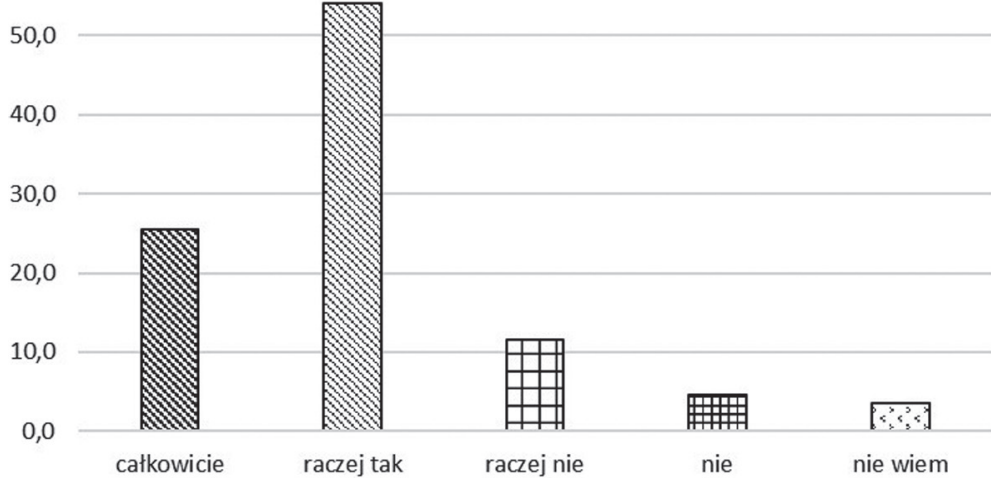

Wykres 5

Śląski powinien być przedmiotem nauczania $w$ szkołach na Śląsku - w \% 50,0

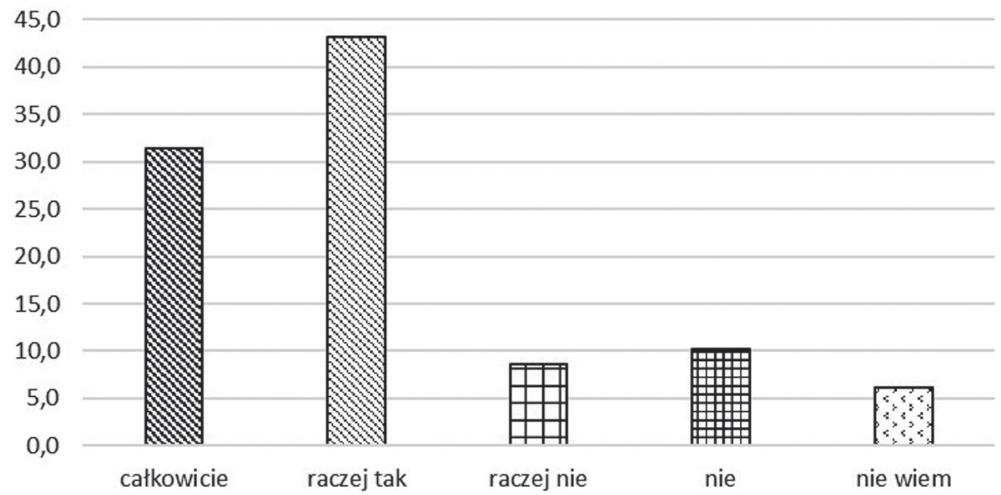




\subsection{2. Śląski jako język urzędowy}

Zupełnie inaczej kształtują się wyniki podsumowujące odpowiedzi na pytanie: Czy śląski powinien zostać językiem urzędowym? Respondenci mieli do wyboru opcje: śląski jako język urzędowy obok polskiego (wykr. 6) lub śląski jako jedyny język urzędowy (wykr. 7):

Śląski powinien stać się na Śląsku językiem urzędowym obok polskiego - $w \%$

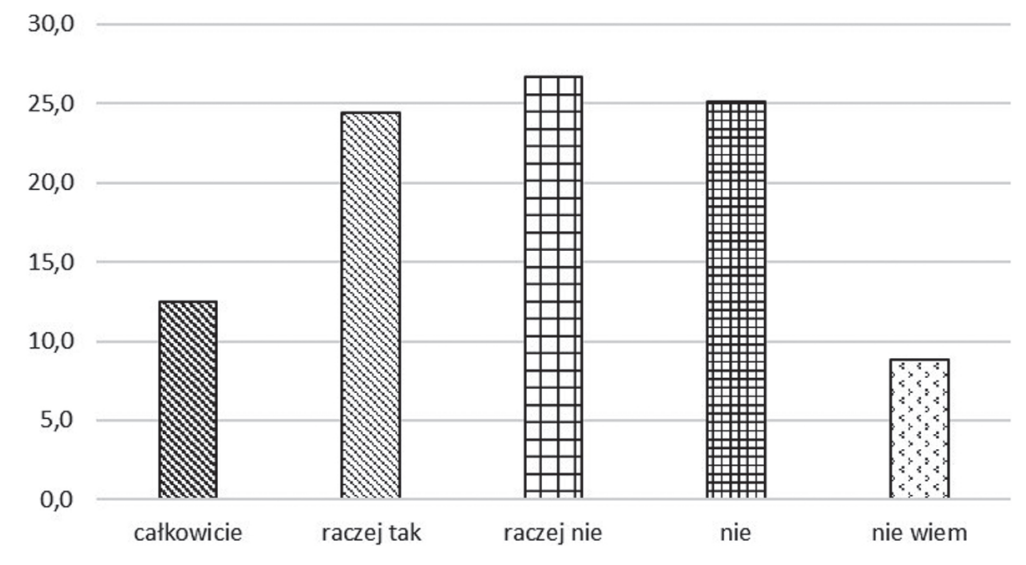

Śląski powinien stać się na Śląsku jedynym językiem urzędowym - w \%

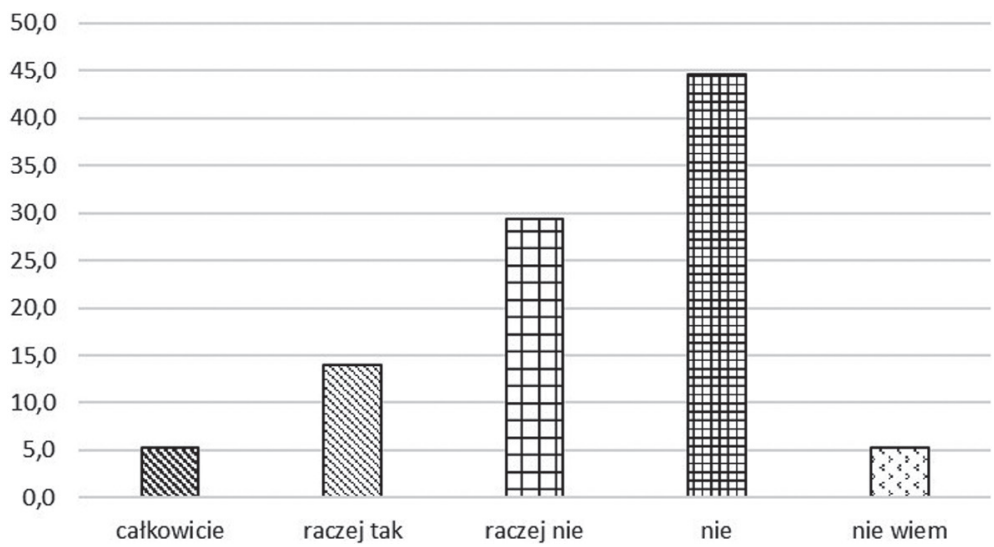

Więcej niż połowa respondentów nie opowiada się nawet za - jakby nie było ostrożniejszym wariantem (wykr. 6). Zwolennicy śląskiego jako języka urzędowego (jednego z języków urzędowych) stanowią jednak nieco powyżej 40\%. Pozostała część biorących udział $w$ badaniu jest niezdecydowana. Respondenci stanowczo odrzucają jednak możliwość uznania śląskiego za jedyny język urzędowy (wykr. 7). Stanowią oni prawie 3/4 ogólnej liczby ankietowanych, z których wyraźna większość (40\% z 75\%) zde- 
Głos $w$ sprawie aktualnego stanu użycia zapożyczeń niemieckich...

cydowanie odrzuca tę opcję. Tylko 5\% pytanych kategorycznie opowiada się za uznaniem śląskiego za jedyny język urzędowy, a niespełna 15\% wybiera odpowiedź „raczej tak” przy tego typu możliwości.

\subsubsection{Pytania dotyczące kodyfikacji}

Ważne są w tym kontekście również dwa pytania (por. wykr. 8 i 9) dotyczące ewentualnej przyszłej kodyfikacji śląskiego. O problemach z akceptacją jednej, ogólnej kodyfikacji z wykorzystaniem kontinuum dialektalnego, które samo w sobie wykazuje znaczące różnice, pisał między innymi Roland MARTI (2018) - na przykładzie retoromańskiego w Szwajcarii. To ważny problem $w$ przypadku lektów, których kodyfikacja jest dopiero przygotowywana lub właśnie przeprowadzana, dlatego te zagadnienia należy również uwzględnić w przypadku śląskiego (por. Hentschel, 2018). Zapytano więc w naszej ankiecie respondentów o to, czy gdyby w szkołach uczono śląskiego, to miałby to być śląski jednolity dla całego Górnego Śląska, czy może jego liczne lokalne warianty:

Wykres 8

Jeżeli uważa Pan/Pani, że śląski powinien być nauczany w szkołach, to które rozwiązanie byłoby lepsze? - w \%

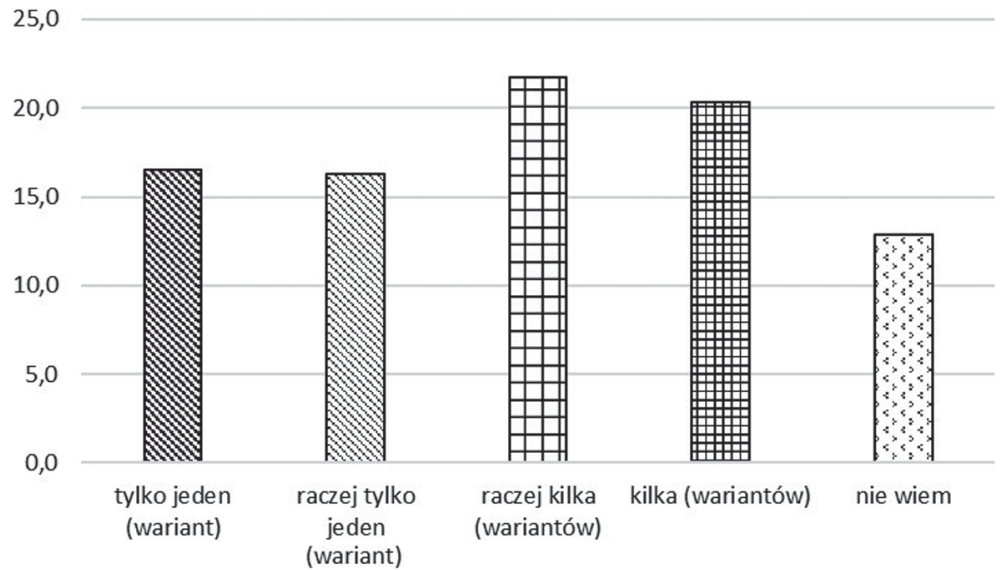

Zwolennicy jednolitego ogólnośląskiego wariantu stanowią mniejszość (ok. 1/3). Opowiadający się za kilkoma wariantami mają niewielką przewagę (stanowią trochę ponad $40 \%$ ). W obu wyborach (jedno- i wielowariantowym) liczba zdecydowanych i ostrożnych głosów jest mniej więcej porównywalna.

Większość respondentów odrzuca rezygnację z germanizmów lub ograniczenie ich udziału w przyszłej ewentualnej kodyfikacji leksykalnej - wyraźna większość w sposób zdecydowany. Około 1/3 wyraża ostrożną akceptację redukcji germanizmów, a tylko bardzo nieliczna grupa (5\%, czyli 5 osób na 100) chciałaby zdecydowanie ich eliminacji: 
Śląski powinien zawierać mniej słów pochodzenia niemieckiego - w \%

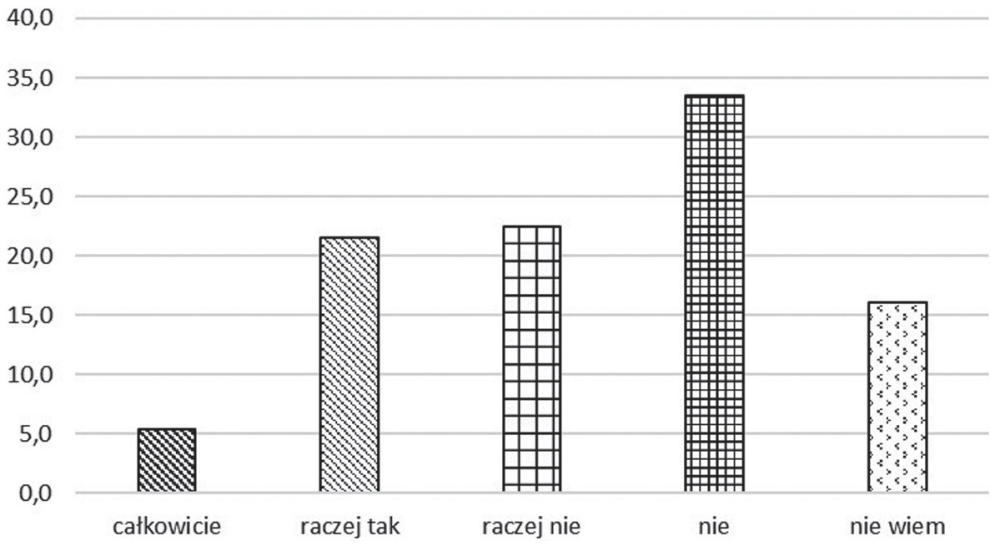

2.2.4. Związki pomiędzy postawami wobec śląskiego i odpowiednimi parametrami socjodemograficznymi

Warto zacząć od stwierdzenia, że brak jest widocznej (godnej wzmianki) zależności pomiędzy wiekiem i wszystkimi rozpatrywanymi postawami wobec śląskiego. Współczynniki korelacji można uznać (jeśli w ogóle są statystycznie istotne) za „bardzo słabe” (Pearson-r $<0,2)$. To samo dotyczy również poziomu wykształcenia. Bardziej istotny statystycznie, chociaż jednak tylko słaby związek (Pearson-r $>0,2$, ale $<0,3$ ) widoczny jest wyłącznie w dwóch wypadkach: (A) Częstsze użycie śląskiego przekłada się (zasadniczo słabo) na wzrost pragnienia jego większej obecności w życiu publicznym. W wypadku wszystkich innych rozpatrywanych tu postaw językowych związek ze wskazanymi zmiennymi socjodemograficznymi zbliża się do zera. (B) Silniejsza tożsamość śląska wiąże się z nieco mocniejszym życzeniem pojawienia się śląskiego jako przedmiotu nauczania w szkołach. Jednak te oczekiwania - zarówno częstszej obecności śląskiego $w$ mediach oraz $w$ życiu publicznym, jak i nadania śląskiemu statusu języka nauczanego w szkole - tak czy owak, niezależnie od omawianego parametru, przeważały liczebnie, co pokazano na wykresach.

\section{Germanizmy}

Wrócimy do tematu relacji pomiędzy różnymi zmiennymi w dalszych rozważaniach. Obecnie jednak zajmiemy się analizą materiału leksykalnego, rozpoczynając od uwag metodologicznych.

\subsection{Metoda - „subiektywna frekwencja” śląskich germanizmów}

Pytanie dotyczące aktywnego użycia słów jest pytaniem o ich częstotliwość, względnie frekwencję użycia. Ponieważ aktualnie nie istnieją i $w$ najbliższym czasie nie powstaną żadne wiarygodne korpusy mówionej odmiany śląskiego, wykluczona jest analiza „obiektywnej frekwencji", której podstawą byłby reprezentatywny zbiór tekstów mówionych i pisanych. 
Głos w sprawie aktualnego stanu użycia zapożyczeń niemieckich...

Alternatywne rozwiązanie stanowi więc analiza „subiektywnej frekwencji”, w której respondenci sami oceniają na skali częstotliwość używania przez siebie wybranych słów. Na potrzeby tych studiów nie pytano ankietowanych o to, jak często w ogóle używają śląskich germanizmów, lecz o to, jak często posługują się jakimś określonym śląskim germanizmem $w$ porównaniu z jego polskim odpowiednikiem znaczeniowym (funkcjonalnym) - wyrazem lub (w pojedynczych wypadkach) wielowyrazowym połączeniem. Chodzi bowiem o to, o ile częściej wybierane są leksemy ze standardowej polszczyzny w stosunku do śląskich germanizmów. Ankietowanym jasno przy tym powiedziano, że chodzi wyłącznie o sytuacje komunikacyjne, w których posługują się śląskim, a nie o sytuacje, w których wybierają polski. Zamieszczamy tu fragment ankiety (por. tab. 10), którą (w obecności ankietującego) musieli wypełnić respondenci. Kolejność elementów w ankiecie ułożono losowo.

Tabela 10

Fragmenty ankiety leksykalnej

\begin{tabular}{|c|c|c|c|c|c|c|c|c|}
\hline & $<1>$ & $<2>$ & $<3>$ & $<4>$ & $<5>$ & $<6>$ & $<7>$ & \\
\hline śląski & głównie & częściej & $\begin{array}{c}\text { jednakowo } \\
\text { często }\end{array}$ & rzadziej & rzadko & $\begin{array}{l}\text { nigdy, } \\
\text { ale znam }\end{array}$ & $\begin{array}{l}\text { nigdy, } \\
\text { bo nie } \\
\text { znam }\end{array}$ & polski \\
\hline ja (potwierdzenie) & & & & & & & & tak \\
\hline ancug & & & & & & & & garnitur \\
\hline luftować & & & & & & & & wietrzyć \\
\hline tasia, tasza & & & & & & & & torba \\
\hline biglować & & & & & & & & prasować \\
\hline gruba & & & & & & & & kopalnia \\
\hline bana & & & & & & & & tramwaj \\
\hline bana & & & & & & & & kolej \\
\hline cug & & & & & & & & ciąg (w kominie) \\
\hline cug & & & & & & & & pociąg \\
\hline
\end{tabular}

Cztery przykłady podane $w$ dolnej części tabeli ilustrują podejście badaczy do homonimii i polisemii. Ankietowani zostali poinformowani, że pewne śląskie słowa występują kilkakrotnie: $w$ różnych znaczeniach - i w związku z tym zestawione są z innymi słowami pochodzącymi ze standardowej polszczyzny.

Badania dotyczą języka mówionego będącego w powszechnym użyciu. Ich przedmiotem jest słownictwo codzienne. Przy wyborze jednostek leksykalnych do ankiety sięgnięto po dwa małe amatorskie słowniki: Słownik śląski (http://www.slownikslaski.pl/) oraz Słowniczek gwary śląskiej - dodatek do książki Ślązoki nie gęsi Marka Szołtyska wydanej w Rybniku w roku 2010. Obu tym słowniczkom przyświeca cel przybliżenia niemówiącym

${ }^{8}$ Temat ten poruszali m.in.: niedawno Tanja Anstatt (2016), wcześniej Wiktor Jassem i Danuta GEMBIAк (1980). 
po śląsku typowego śląskiego słownictwa (słowniki, oczywiście, nie ograniczają się do germanizmów) i obydwa w dużym stopniu zawierają tę samą leksykę. Słownictwo fachowe (przykładowo z zakresu górnictwa i hutnictwa) - jeśli zakłada się, że nie funkcjonuje $w$ powszechnym użyciu - nie zostało uwzględnione w naszych ankietach.

Spośród germanizmów figurujących w obu eksplorowanych źródłach starano się wybrać jedynie takie, które uznano za „specyficznie śląskie”. Wiele spośród nich bez wątpienia można znaleźć także $w$ innych polskich subwariantach: fajrant < Feierabend, mantel < Mantel, mycka < Mütze, platfus < Plattfuß, pucować < putzen, szychta < Schicht (w pracy zmianowej). Przykłady te są między innymi rozpowszechnione również $w$ dialekcie małopolskim (por. SGM). Takie leksemy nie zostały wyłączone z ankiety. Rodzi się wszak pytanie: Czy fakt obecności pojedynczych germanizmów $w$ innych polskich subwariantach ma wpływ na aktywne użycie (przynajmniej niektórych) germanizmów w lekcie śląskim? Wedle danych demograficznych około 2/3 dzisiejszej ludności Śląska nie wywodzi się z rdzennie śląskich rodzin. Można więc wysnuć hipotezę, że użycie śląskich germanizmów zostaje wzmocnione, gdy ludność napływowa w języku potocznym „przyniosła” na Śląsk te same jednostki leksykalne. Germanizmy, które są wspólne dla lektu śląskiego i standardowej polszczyzny, $z$ oczywistych względów zostały pominięte $w$ tym projekcie.

W ankiecie uwzględniono 689 germanizmów rozumianych jako jednostki testowe. Wypełnienie obu części ankiety - socjodemograficznej i leksykalnej - trwało łącznie około 2,5 godziny, co świadczy o jej pokaźnej objętości. Kontroli poddano niedające się do końca wyeliminować ryzyko pojawienia się u ankietowanych efektu zmęczenia. Aby zbadać efekt kolejności (pozycji prezentowania słów), zbudowano uogólniony model addytywny (por. Wood, 2006) do przetestowania zależności nielinearnych. W tym celu skorzystano z tzw. mgcu R Package (Wood, 2009). Pozycja słów i standardowe odchylenia pełnią w modelu funkcję „wygładzacza”. Okazało się, że pozycja elementów w ankiecie nie była żadnym wskaźnikiem ocen $(F=0,854, p=0,472)$. Kolejność nie miała więc na nie żadnego wpływu.

\subsection{Analiza - zarys}

Częstotliwość użycia śląskich germanizmów w porównaniu do ich ekwiwalentów ze standardowej polszczyzny można było zaznaczyć na skali od 1 do 7. Skrajne wartości zostały dla każdego spośród 689 wyrazów wskazane choć jeden raz, tzn. zawsze przynajmniej jeden ankietowany (z reguły oczywiście czyniło to o wiele więcej osób) wybrał odpowiedź 1 lub 7. Tylko trzy leksemy były znane wszystkim ankietowanym, czyli nigdy nie otrzymały wartości 7: bryle < Brille, mantel < Mantel, bajtel < (najprawdopodobniej z gwarowej postaci niem.) Beutel 'dziecko' (choć znaczy to i bojtel 'woreczek'). A oto kilka ankietowych przykładów o skrajnych wartościach użycia (tab. 11):

${ }^{9}$ Obecnie trwa sprawdzanie testowanych jednostek leksykalnych $w$ innych polskich subwariantach. 
Głos w sprawie aktualnego stanu użycia zapożyczeń niemieckich...

Tabela 11

Najwyższa i najniższa subiektywna frekwencja germanizmów

\begin{tabular}{|c|c|c|c|c|}
\hline $\begin{array}{l}\text { Jednostki wyrazowe } \\
\text { (śląskie - polskie) }\end{array}$ & $\begin{array}{l}N-\text { uwzględ- } \\
\text { nionych }\end{array}$ & $\begin{array}{c}N-\text { brakują- } \\
\text { cych }\end{array}$ & $\begin{array}{l}\text { Wartość } \\
\text { średnia }\end{array}$ & $\begin{array}{l}\text { Standardowe } \\
\text { odchylenie }\end{array}$ \\
\hline \multicolumn{5}{|c|}{ GERMANIZMY BARDZO CZESTO UŻYWANE } \\
\hline ja - tak (potwierdzenie) & 439 & 3 & 1,48 & 0,936 \\
\hline ała! - boli! (okrzyk z bólu) & 440 & 2 & 1,66 & 1,264 \\
\hline hasiok - śmietnik & 442 & 0 & 1,83 & 1,309 \\
\hline cygarety, cigarety - papierosy & 442 & 0 & 1,86 & 1,365 \\
\hline farorz, farorzyczek - proboszcz, ksiądz & 442 & 0 & 1,93 & 1,378 \\
\hline marasić - brudzić & 437 & 5 & 1,94 & 1,350 \\
\hline maras - błoto, brud & 440 & 2 & 1,95 & 1,357 \\
\hline familok - (stara śląska) kamienica & 440 & 2 & 1,98 & 1,455 \\
\hline fara - probostwo, plebania & 440 & 2 & 1,98 & 1,465 \\
\hline kapuca - kaptur & 439 & 3 & 2,01 & 1,480 \\
\hline luftować - wietrzyć & 441 & 1 & 2,01 & 1,407 \\
\hline \multicolumn{5}{|c|}{ GERMANIZMY PRAWIE NIGDY NIEUŻYWANE } \\
\hline blindar - ślepa kiszka & 436 & 6 & 6,22 & 1,495 \\
\hline umsztajgyn - przesiadka & 440 & 2 & 6,23 & 1,476 \\
\hline ańfachowy - zwyczajny, byle jaki, prostacki & 439 & 3 & 6,25 & 1,602 \\
\hline szlagbal - piłka do palanta / palant & 440 & 2 & 6,25 & 1,585 \\
\hline erplich - spadek, coś po kimś & 439 & 3 & 6,26 & 1,480 \\
\hline tintynfas - kałamarz & 437 & 5 & 6,30 & 1,438 \\
\hline blizablajfer - piorunochron & 440 & 2 & 6,31 & 1,516 \\
\hline bronok - ktoś brazowy, brązowy koń & 441 & 1 & 6,41 & 1,366 \\
\hline griner - zielona żaba & 441 & 1 & 6,51 & 1,260 \\
\hline
\end{tabular}

Jak się spodziewano, ocena częstości użycia poszczególnych jednostek charakteryzuje się pewnym stopniem wariancji (por. standardowe odchylenia w górnej części tabeli). Wariancja zasadniczo rośnie (widoczna w wartości standardowego odchylenia), im bardziej poszczególne wartości średniego użycia poddanych badaniu jednostek leksykalnych odbiegają od ekstremów 1 i 7, czyli przesuwają się ku środkowi skali ocen ${ }^{10}$ - to banalny efekt arytmetyczny. By wstępnie ocenić efekty badania wszystkich 689 jednostek, należy przyjrzeć się najczęstszym wartościom „środkowej tendencji”: arytmetycznemu centrum. Na początek wystarczy połączyć poszczególne średnie wartości w 4 grupy (wykr. 10):

${ }^{10}$ Metoda jak wyżej za: Wood (2006): $F=11,494, p<0,001$. 
Średnie wartości użycia poszczególnych germanizmów w 4 grupach (frekwencja użycia germanizmów w porównaniu z polskimi ekwiwalentami)

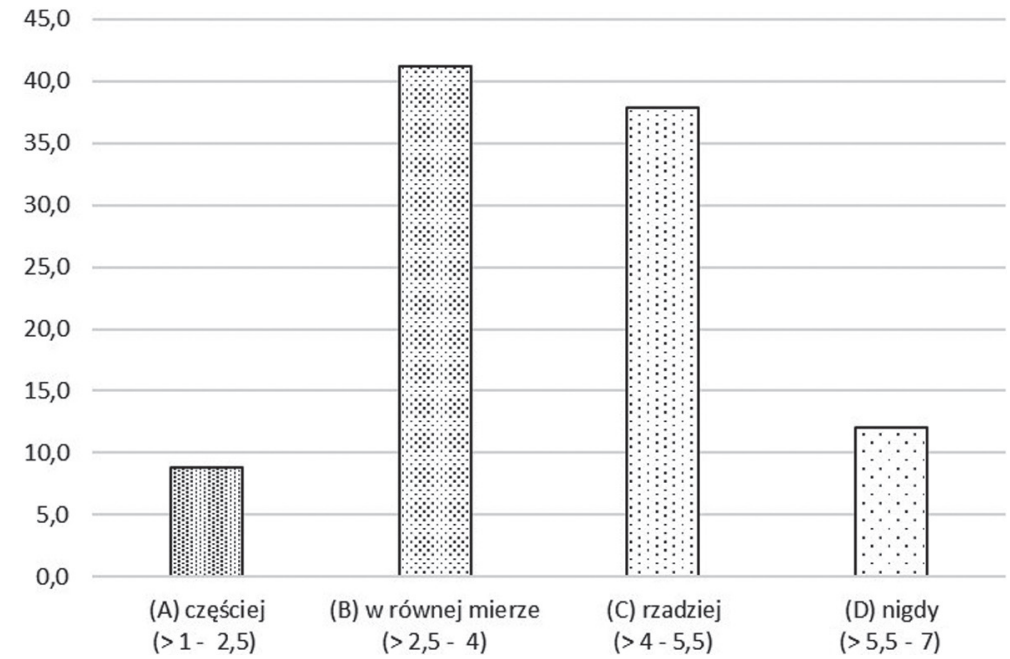

Prawie co ósma testowana jednostka wedle ankietowanych nie bywa nigdy używana (słupek D). Do takich jednostek należą germanizmy w dolnej części tabeli 11. Tylko niespełna 10\% jednostek jest zasadniczo częściej używanych niż ich ekwiwalenty ze standardowej polszczyzny (słupek A). Do nich należą germanizmy w górnej części tabeli 11. Niemal czterokrotnie większa jest liczba śląskich germanizmów z tendencją do rzadszego użycia (słupek C). Najliczniejszą grupę stanowią te germanizmy, które mają podobną częstotliwość użycia do ich ekwiwalentów ze standardowej polszczyzny (słupek B).

Ten wynik potwierdza nasze przypuszczenie, że germanizmy w lekcie śląskim prawie siedemdziesiąt pięć lat po II wojnie światowej wycofują się z użycia, a w dużej mierze już nawet się wycofały ${ }^{11}$. Jednak stopień wariancji jest nadal wysoki.

\subsection{Wymiar wariancji}

\subsubsection{Wiek}

Obserwacja stopniowego zaniku germanizmów w lekcie śląskim prowadzi do kolejnego przypuszczenia, że są one bardziej rozpowszechnione wśród starszych użytkowników śląszczyzny niż wśród młodszych. Dlatego oblicza się ogólny związek między wiekiem (rokiem urodzenia) i indywidualnymi wartościami średnimi dla każdego z respondentów. Wyliczenia

11 Taką tendencję opisywała na podstawie wywiadów TAмBor (2008), prezentując wypowiedzi respondentów. Opinię o zanikaniu germanizmów autorka formułowała zarówno na podstawie analizy wybranych wypowiedzi pod względem składu leksykalnego, jak i opinii metajęzykowych badanych osób. Należy też dodać, że jeśli w miejsce zanikających germanizmów do śląszczyzny włączane są wyrażenia ze standardowej polszczyzny, to najprawdopodobniej podlegają fonetycznej i morfologicznej adaptacji, co zasługuje na zbadanie. 
Głos w sprawie aktualnego stanu użycia zapożyczeń niemieckich...

potwierdzają taki związek - jest on wprawdzie słaby, choć bardzo istotny statystycznie (Pearson- $r=0,235, p=<0,01$ ).

Ciekawsze wszak wyniki niż analiza związku pomiędzy wiekiem i subiektywną frekwencją w całym zbiorze jednostek przynosi obliczenie tych związków w sposób zróżnicowany dla poszczególnych jednostek wyrazowych. Na początek należy stwierdzić, że dla 222 jednostek nie istnieje związek nawet o słabej istotności statystycznej między subiektywną frekwencją i wiekiem. Około 450 wartości zaś jest istotnych statystycznie i wskazuje na co najmniej słabe związki (Pearson-r $\geq 0,2 ; p<0,05$, wartość skorygowana ${ }^{12}$ ). Użycie germanizmów przez starszych i młodszych mimo wszystko jeszcze silnie się pokrywa, co poświadcza fakt istnienia tylko słabych związków między oboma parametrami. W przypadku pewnych jednostek dolna wartość wskaźnika korelacji jest ujemna, co dowodzi, że określone germanizmy używane bywają częściej przez młodsze osoby ${ }^{13}$. Takie przykłady są jednak nieliczne. Duża liczba jednostek wykazuje wysoką frekwencję u starszych użytkowników śląszczyzny. Dla obu grup germanizmów (częstszych u młodszych / częstszych u starszych) zamieszczamy tylko 5-6 najbardziej oczywistych przykładów (tab. 12).

Tabela 12

Germanizmy preferowane przez starszych i młodszych respondentów

\begin{tabular}{|c|c|c|c|c|}
\hline $\begin{array}{l}\text { Jednostki wyrazowe } \\
\text { (śląskie - polskie) }\end{array}$ & $\begin{array}{c}N-\text { uwzględ- } \\
\text { nionych }\end{array}$ & $\begin{array}{c}N-\text { brakują- } \\
\text { cych }\end{array}$ & $\begin{array}{l}\text { Wartość } \\
\text { średnia }\end{array}$ & $\begin{array}{l}\text { Współczynnik } \\
\text { Pearson- } r^{*}\end{array}$ \\
\hline \multicolumn{5}{|c|}{ GERMANIZMY CZESTSZE U MŁODSZYCH } \\
\hline lukać, luknońć - spoglądać, spojrzeć & 437 & 5 & 3,40 & $-0,284$ \\
\hline szlajać sie - włóczyć się & 440 & 2 & 2,57 & $-0,268$ \\
\hline kapnońć sie - zrozumieć, zorientować się & 437 & 5 & 2,16 & $-0,267$ \\
\hline mus (jak mus to mus) - konieczność & 440 & 2 & 2,13 & $-0,225$ \\
\hline maras - błoto, brud & 440 & 2 & 1,95 & $-0,205$ \\
\hline \multicolumn{5}{|c|}{ GERMANIZMY CZESTSZE U STARSZYCH } \\
\hline bakpulwer - proszek do pieczenia & 441 & 1 & 4,70 & 0,414 \\
\hline cwist - wełna, przędza, włóczka do cerowania & 439 & 3 & 5,33 & 0,415 \\
\hline ablyger, ablyjger - sadzonka & 440 & 2 & 4,99 & 0,418 \\
\hline cetnor $-50 \mathrm{~kg}$ & 442 & 0 & 4,41 & 0,420 \\
\hline bratheringi, brateringi - śledzie opiekane & 440 & 2 & 4,11 & 0,429 \\
\hline bonkawa - kawa (naturalna) & 440 & 2 & 4,79 & 0,431 \\
\hline
\end{tabular}

* Wszystkie $p<0,001$, nieskorygowane względnie $p<0,01$ skorygowane wg Holma-Bonferroniego.

${ }^{12}$ W przypadku dużego zbioru zmiennych zaleca się dokonanie korekty wartości istotności statystycznej korelacji wg Pearsona, ponieważ nie jest wykluczone, że z powodu tzw. błędu typu I ( $\alpha)$ zbyt wiele współczynników zostaje uznanych za istotne (por. Peres-Neto, 1999). Tzw. efekt korekty Holma-Bonferroniego (Holm, 1979) polega na tym, że rosną wartości istotności statystycznej, w wyniku czego pewna liczba wartości istotności statystycznej przekracza wartość progową $p=0,05$, przez co oceniane są one jako istotne. Jeśli w tekście mówi się o skorygowanych wartościach istotności, chodzi o takie właśnie sprawdzenie.

13 Do obliczeń wykorzystano rok urodzenia, dla którego - co oczywiste - obowiązuje reguła: im wyższa wartość, tym młodsza osoba. 
W grupie germanizmów częściej używanych przez młodszych użytkowników na komentarz zasługują co najmniej dwa leksemy wymienione w tabeli 12: pierwszy - lukać, luknońć, i trzeci - kapnońć sie. Oba bowiem występują w potocznej polszczyźnie młodego pokolenia Polaków, są notowane przez wszystkie ogólnopolskie słowniki potocznej polszczyzny i slangu młodzieżowego. Wzmocnione przez potoczną polszczyznę ogólną jest na pewno także użycie czasownika szlajać się, również notowane przez słowniki języka polskiego i opatrzone kwalifikatorem 'potoczne'. Ale - jak już wspomniano - w ramach projektu należy sprawdzić, $w$ jakim stopniu obecność określonych germanizmów $w$ innych subwariantach polszczyzny wpływa na ich użycie w śląskim etnolekcie. Wszystkie 689 jednostek poddanych analizie jest obecnie porównywanych $z$ hasłami notowanymi $w$ SGP (i w jego kartotece) oraz $w$ słownikach slangu i potocznej polszczyzny. Poza tym z całą pewnością jeszcze kolejne nieliczne jednostki zostaną wyłączone z dalszych badań, gdy podczas trwających już - dla pewnych jednostek - szczegółowych analiz etymologicznych zrodzą się poważne wątpliwości co do ich statusu jako germanizmów. Do takich budzących zastrzeżenia jednostek należy właśnie lukać, luknońć. Ich sprawdzenie $w$ kartotece SGP (za które dziękujemy Bogusławowi Wyderce) wykazało, że w zasadzie na pewno pochodzą one bezpośrednio od angielskiego look. Ponieważ wszystkie notowane cytaty są młodsze, praktycznie wykluczone jest ich pochodzenie od niem. lugen 'widzieć, patrzeć' lub Luke 'okienko'.

\subsection{2. Śląskie nasycenie językowe}

Jest to złożony atrybut, który został obliczony na podstawie informacji na temat częstotliwości użycia lektów śląskiego i polskiego. Przygotowano ośmiostopniową skalę (tab. 13):

Tabela 13

Obliczenie stopnia śląskiego nasycenia językowego respondentów

\begin{tabular}{|c|c|c|c|c|c|}
\hline $\begin{array}{c}\text { Używanie lektu } \\
\text { śląskiego }\end{array}$ & $\begin{array}{c}\text { Punkty za } \\
\text { częstotliwość } \\
\text { używania } \\
\text { śląskiego lektu }\end{array}$ & $\begin{array}{c}\text { Używanie } \\
\text { języka polskiego }\end{array}$ & $\begin{array}{c}\text { Śląski } \\
\text { w porównaniu } \\
\text { z polskim }\end{array}$ & $\begin{array}{c}\text { Punkty } \\
\text { z porównania }\end{array}$ & $\begin{array}{c}\text { Stopień językowego } \\
\text { ześląszczenia }\end{array}$ \\
\hline I & II & III & IV & V & VI \\
\hline bardzo często & 3 & rzadko (nigdy) & $\mathrm{s} \gg>p$ & 6 & 9 \\
\hline bardzo często & 3 & czasami & $\mathrm{s} \gg \mathrm{p}$ & 5 & 8 \\
\hline bardzo często & 3 & często & $s>p$ & 4 & 7 \\
\hline często & 2 & rzadko & $s \gg p$ & 5 & 7 \\
\hline bardzo często & 3 & bardzo często & $\mathrm{s}=\mathrm{p}$ & 3 & 6 \\
\hline często & 2 & czasami & $s>p$ & 4 & 6 \\
\hline często & 2 & często & $\mathrm{s}=\mathrm{p}$ & 3 & 5 \\
\hline często & 2 & bardzo często & $\mathrm{s}<\mathrm{p}$ & 2 & 4 \\
\hline czasami & 1 & często & $\mathrm{s}<\mathrm{p}$ & 2 & 3 \\
\hline czasami & 1 & bardzo często & $\mathrm{s}<<\mathrm{p}$ & 1 & 2 \\
\hline
\end{tabular}


Głos w sprawie aktualnego stanu użycia zapożyczeń niemieckich...

Stopień śląskiego nasycenia językowego uwzględnia informacje dotyczące częstotliwości używania lektu śląskiego (I kolumna) i porównanie z częstotliwością używania języka polskiego (IV kolumna). Za oba aspekty przyznawano określoną liczbę punktów (II lub V kolumna), których suma stanowi miarę śląskiego nasycenia językowego. Większą rolę przypisuje się przy tym porównaniu użycia śląskiego i polskiego niż samej częstotliwości używania języka polskiego.

Analiza ujawnia stan rzeczy podobny do zaobserwowanego w przypadku kryterium wieku. Kilkaset testowanych jednostek wskazuje na zależność od stopnia częstości używania śląskiego lektu, czyli stopnia śląskiego nasycenia językowego. Jest ich nawet nieco więcej niż w wypadku kryterium wieku (zależności istotne statystyczne Pearson- $r>0,2, p<0,05$ wartość skorygowana), co zapewne ma wyraźny związek z sytuacją przełączania kodów i mniej lub bardziej świadomych (częściej nieświadomych) wynikających stąd interferencji, także leksykalnych (zob. np. КURек, 1987; ТАмвоR, 2013), i może mieć wpływ na trwałość germanizmów $w$ idiolektach respondentów. Podobnie jak $w$ przypadku wieku wszystkie zależności są słabe. Jednak wartości zmiennych są nieco niższe $w$ stosunku do odnotowanych $w$ przypadku wieku. Maksymalna wartość wynosi $r=-0,381^{14}$ (w przypadku wieku: 0,431). Nie ma żadnych przeciwnych zależności, co można było zaobserwować w wypadku kategorii wieku (niektóre germanizmy wydają się - jak już wspomniano - bardziej rozpowszechnione wśród młodszych ankietowanych). Nie ma zatem (ze zrozumiałych względów) germanizmów, które byłyby częściej używane przez osoby o niskim poziomie śląskiego nacechowania językowego, czyli u osób, które lektem śląskim posługują się relatywnie rzadziej niż językiem ogólnopolskim. W tym miejscu można zrezygnować z przedstawienia przykładów.

\subsubsection{Powiązania kryterium wieku i stopnia śląskiego nasycenia językowego z innymi parametrami}

Dla innych parametrów, takich jak stopień identyfikacji etniczno-narodowej (Ślązak lub nie) czy poziom wykształcenia, nie stwierdzono żadnych istotnych statystycznie związków z używaniem germanizmów, które można by zakwalifikować przynajmniej jako słabe. Silna śląska tożsamość nie przekłada się na upodobanie do germanizmów, a niższy poziom wykształcenia również nie idzie $w$ parze z częstszą obecnością germanizmów w języku ankietowanych.

Przedstawione dotąd analizy zależności opierają się na tzw. dwuczynnikowych analizach korelacji. Wadą tej metody jest nieuwzględnianie relacji pomiędzy zmiennymi niezależnymi. Jeśli na przykład stopień śląskiego nasycenia językowego (proporcjonalnie) w sposób istotny statystycznie byłby skorelowany z wiekiem, to niemożliwe byłoby rozstrzygnięcie, jaką rolę odgrywa każda z dwóch zmiennych, czyli która z nich ma decydujący wpływ na zmienną zależną. Dlatego wskazany jest powrót do metody wieloczynnikowej, w której uwzględnia się wszystkie potencjalne relacje między badanymi zmiennymi (również niezależnymi), co pozwala wyliczyć znaczenie zmiennej w „czystej formie”.

${ }^{14}$ Wartość jest ujemna, ponieważ najwyższy stopień śląskiego nasycenia językowego został oznaczony cyfrą 9, a najwyższa wartość subiektywnej frekwencji - cyfrą 1. 
Taką metodą jest tzw. conditional inference tree (drzewo wnioskowania warunkowego), rodzaj drzewa decyzyjnego (por. np. Levshina, 2015), przy czym ograniczamy się tu do określenia odpowiednich kryteriów, które pokazują istotny statystycznie związek z częstotliwością pojedynczych jednostek, mierzoną za pomocą indywidualnych wartości średnich, charakterystycznych dla poszczególnych respondentów. Drzewa wnioskowania warunkowego szczególnie wtedy są pomocne przy klasyfikacji, gdy mamy do czynienia - tak jak $w$ tym przypadku - z wieloma zmiennymi niezależnymi ${ }^{15}$ (por. schemat 1).

Jako zmienne niezależne uwzględniono również wszystkie już wspomniane kryteria socjodemograficzne, takie jak rok urodzenia (dodatkowo grupę wiekową), region, stopień śląskiego nasycenia językowego (poza tym wiele zmiennych wynikających z odpowiedzi na pytania, gdzie, z kim i jak często ankietowany rozmawia po śląsku), poziom i typ wykształcenia oraz omówione postawy językowe w stosunku do lektu śląskiego:

Drzewo wnioskowania warunkowego dla kryteriów wskazujących na stopień subiektywnej frekwencji

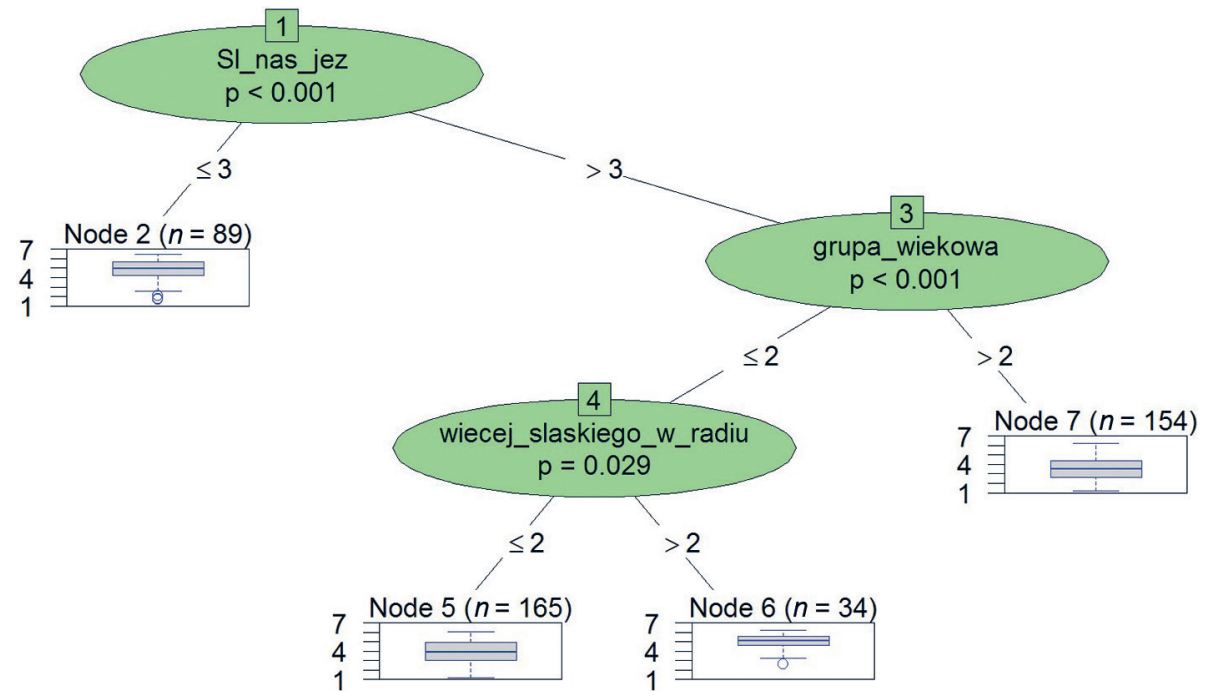

Przedstawiony schemat należy czytać $w$ następujący sposób: stopień śląskiego nasycenia językowego jest najważniejszą cechą przy prognozowaniu zmiennej zależnej, tzn. częstotliwości użycia germanizmów (poprzez podaną uśrednioną wartość jednostek leksykalnych na osobę). Gałęzie drzewa należy rozumieć jako kombinacje warunków. Wartości podane na konarach drzewa są wartościami progowymi (3 jest więc wartością progową zmiennej „śląskie nasycenie językowe”). Im wyższy predykator (zmienna) znajduje się $w$ drzewie, tym jest on ważniejszy przy prognozowaniu zmiennej zależnej. Wszystkie zmienne niezależne, które pojawiają się na drzewie, są statystycznie istotnymi predyka-

${ }^{15}$ Analizie regresji wielokrotnej np. nie można poddać tak wielu zmiennych, które brane są pod uwage $w$ tych studiach, por. Levshina (2015). 
Głos w sprawie aktualnego stanu użycia zapożyczeń niemieckich...

torami (próg skorygowany według Bonferroniego). Inne potencjalne zmienne nie wnoszą niczego do klasyfikacji ${ }^{16}$.

Jeśli stopień śląskiego nasycenia językowego (w schemacie 1: SI_nas_jez) jest słaby, tzn. równy lub niższy od 3 (zob. poprzedni akapit), mediana dla użycia germanizmów przez 89 respondentów jest zwykle wysoka (ok. 5), co oznacza, że germanizmy są zasadniczo wyraźnie rzadziej używane niż ich ekwiwalenty ze standardowej polszczyzny. Jeśli stopień śląskiego nasycenia językowego jest wyższy niż 3, rolę odgrywa wówczas wiek (grupa wiekowa). W najstarszej grupie (> 2, tzn. urodzonych w 1968 r. lub wcześniej) mediana jest dość niska (poniżej 4), co oznacza, że użycie germanizmów przez starszych ankietowanych (154) jest częstsze. Już dwuczynnikowe analizy korelacji sugerowały znaczenie śląskiego nasycenia językowego i wieku. W przypadku młodszych ankietowanych (urodzonych w 1969 r. lub później) ważną rolę odgrywa jeszcze trzecie kryterium, a mianowicie pragnienie, by lekt śląski był bardziej obecny $w$ radiu. Ponieważ kryterium to $w$ sposób istotny łączy się z ogólnym założeniem, by śląski był mocniej obecny w życiu społecznym, możemy interpretować je $w$ kategorii substytutu ogólnego pragnienia, ogólnej potrzeby. Gdy takie oczekiwanie istnieje (wyrażane w sposób zdecydowany lub umiarkowany przez 165 ankietowanych), mediana jest dość niska i wynosi 4. Jeśli młode osoby nie wyrażają życzenia, by śląski lekt był wyraźniej obecny w życiu publicznym (34 ankietowanych), wartość mediany rośnie do 6, co praktycznie jest równoznaczne z nieużywaniem w ogóle germanizmów przez danego respondenta. Czytelnikowi, który nie zna tej metody analizy, wskazane różnice wartości mogą wydawać się niewielkie. Nie chodzi tu jednak o bezpośrednie porównanie wartości głównej tendencji, lecz o rodzaj weryfikacji istotności tych kryteriów i sprawdzenie, czy osiągają wysokie czy niskie wartości.

Jeśli życzenie, by lekt śląski był bardziej obecny w społeczeństwie, będziemy rozumieć jako przejaw sympatii do śląskiego, to bardziej zrozumiałe statystycznie staje się używanie germanizmów przez młodych respondentów wyrażających takie pragnienie niż przez tych, którzy takiej potrzeby nie widzą. Przekonujący jest również wniosek, że spośród osób o wysokim stopniu językowego nasycenia śląskiego (tych, które $w$ porównaniu z polskim używają śląskiego dość często) germanizmy pojawiają się zwykle częściej u reprezentantów starszych roczników, gdyż osoby te jeszcze sprzed lat znają germanizmy, które w dzisiejszych realiach nie odgrywają już żadnej (lub istotnej) roli. Najważniejszym warunkiem (ponownego) sięgnięcia po germanizmy jest jednak co najmniej równa częstość używania śląskiego i polskiego, czyli wysoki stopień użycia lektu śląskiego przez indywidualnych użytkowników.

\section{Podsumowanie i perspektywy}

Przedstawione wyniki mają, oczywiście, charakter sondażowy (choć 500 ankiet spośród projektowanych 2000 rezultaty dość dobrze uwiarygodnia). Zbieranie danych na potrzeby

${ }^{16}$ Liczba przypadków n odnosi się do ogólnej liczby przypadków, które klasyfikowane są zgodnie z algorytmem (regułą) prezentowanym na schemacie. Różne sposoby/warunki prognozują w idealnym przypadku różne zakresy skali zmiennej zależnej, a więc częstości używania germanizmów. 
projektu jest już właściwie ukończone, jednak ich analiza zajmie jeszcze sporo czasu. Przede wszystkim $w$ materiale dotąd zanalizowanym poszczególne regiony badanego terenu nie są jeszcze wystarczająco reprezentowane. Dotyczy to także niektórych zawodów. Również inne aspekty odnoszące się do materiału leksykalnego nie mogły jeszcze zostać uwzględnione $w$ przedstawionej analizie. Wymieńmy chociażby tylko dwa spośród nich. Po pierwsze: znaczenie obecności rzekomo „śląskich” germanizmów na sąsiednim obszarze dialektów małopolskiego i wielkopolskiego oraz ich ewentualnego funkcjonowania $w$ polszczyźnie potocznej; po drugie: różnice frekwencji germanizmów w poszczególnych kręgach tematycznych („polach semantycznych”). Jednak duża liczba poddanych analizie ankiet (442, co stanowi ok. 1/4 zamierzonej liczby) pozwala już zaobserwować pewne istotne tendencje. Dotyczą one zarówno postaw, jak i pragnień, oczekiwań aktywnych użytkowników lektu śląskiego, a także kwestii obecności śląskich germanizmów w ich mowie.

W przypadku tych ostatnich nie może być żadnych wątpliwości co do tego, że prawie połowa analizowanych jednostek leksykalnych w porównaniu z ich ekwiwalentami ze standardowej polszczyzny używana jest już wyłącznie rzadko lub nie jest nigdy używana. Nie można jednak nie zauważyć, że liczba germanizmów, które wykazują podobną subiektywną frekwencję jak ich polskie odpowiedniki, osiągając poziom 40\%, jest również znacząca, a prawie $10 \%$ tych pierwszych jest zdecydowanie częściej używanych niż te drugie. Ostatnia grupa leksemów to centralny zbiór nadal aktywnie używanych w lekcie śląskim germanizmów.

Analiza preferencji użycia polskiego lub śląskiego pokazuje, że Ślązacy są bilingwalni lub „dwukodowi” (posługują się podwójnym kodem) z tendencją do wyboru tradycyjnego podziału dyglosyjnego. Większość życzy sobie wzrostu użycia śląskiego (bez zajmowania radykalnych stanowisk) $w$ mediach, w szkołach i $w$ sferze życia publicznego. Jednak, co trzeba wyraźnie podkreślić, większość (nawet spośród aktywnych użytkowników śląskiego), jeśli nie odrzuca pomysłu nadania śląskiemu statusu języka urzędowego, to jest wobec niego sceptyczna. Śląski jest więc raczej symbolem „małej ojczyzny”, traktowanej jako część większej - Polski. Z taką oceną pozostają w zgodzie zwykle także identyfikacje etniczne ankietowanych. Opinie na temat typu przyszłej kodyfikacji: jednolita czy ograniczona i zróżnicowana subregionalnie - są w zasadzie statystycznie zrównoważone, z lekką przewagą dla uwzględnienia różnic regionalnych. Jednak ewentualne ograniczanie liczby germanizmów $w$ kodyfikacji nie spotkało się z poparciem większości.

Co to oznacza dla przyszłej możliwej kodyfikacji lektu śląskiego? Kompleksowa odpowiedź na to istotne politycznie pytanie nie leży w gestii autorów spoza Polski ani nawet $w$ gestii powołanego międzynarodowego zespołu badawczego, który postanowił zjawisko zbadać, starając się na każdym etapie zachować maksimum naukowego - językoznawczego, $w$ tym także socjolingwistycznego - obiektywizmu. Ale przynajmniej w sprawie germanizmów można wyraźnie stwierdzić, że rezygnacja z najczęściej używanych jednostek tego typu wydaje się - przy oczywistym dążeniu kodyfikatorów do akceptacji kodyfikacji (lub wielu subregionalnych częściowych kodyfikacji) - niewskazana, ponieważ nie jest zgodna z oczekiwaniami większości aktywnych użytkowników śląskiego. Nie należy jednak nadinterpretowywać tych oczekiwań, ponieważ $w$ domyśle dotyczą one głównie germanizmów wciąż aktywnie używanych. Z pewnością nie ma potrzeby uwzględniania germanizmów 
Głos $w$ sprawie aktualnego stanu użycia zapożyczeń niemieckich...

dziś już rzadkich lub w ogóle nieużywanych (nawet jeśli jeszcze częściowo zrozumiałych) w zamian za prognozowaną zwiększoną liczebnie akceptację kodyfikacji.

\section{Słowniki}

SGM - Wronicz J., red., 2016-2017: Słownik gwar małopolskich. T. 1-2. Kraków.

SGP - Słownik gwar polskich PAN, 1979-2018: T. 1-10. Wrocław-Kraków.

Słowniczek gwary śląskiej. W: SzoŁTYSEK M., 2010: Ślązoki nie gęsi, czyli Konski nojfajniyjszych ksiqżek na świecie przełonaczone na śląsko godka. Rybnik.

Słownik śląski [online: http://www.slownikslaski.pl/].

\section{Literatura}

Adelung J.C., 1809: Mithridates oder allgemeine Sprachenkunde mit dem Vater Unser als Sprachprobe in beynahe fünfhundert Sprachen und Mundarten... Teil 2. Berlin.

Anstatt T., 2016: Subjektive Frequenz als Forschungsmethode. „Wiener Slawistischer Almanach” LXXVII, S. 7-35.

CzESAK A., 2015: Współczesne teksty śląskie na tle procesów językotwórczych i standaryzacyjnych współczesnej Słowiańszczyzny. Kraków.

Grybosıowa A., 1998: Wartościowanie gwary śląskiej. Mity i rzeczywistość. W: Wolı́́sKA O., red.: Prace językoznawcze. T. 25: Studia historycznojęzykowe. Katowice, s. 40-47.

Hentschel G., 2018: Śląski: gwara - dialekt - język? Spojrzenie z zewnatrz. W: TAmbor J., red.: Polonistyka na początku XXI wieku. Diagnozy - koncepcje - perspektywy. T. 4: Pogranicza, mniejszości, regiony. Etnolingwistyka. Katowice, s. 41-66.

Holm S., 1979: A Simple Sequentially Rejective Multiple Test Procedure. „Scandinavian Journal of Statistics" VI, nr 2, s. 65-70.

Jassem W., GEмвіAк D., 1980: Subiektywne prawdopodobieństwo wyrazów polskich. Warszawa-Poznań.

Косува P., 2015: Sprachenkampf, Sprachkontakt und Sprachstatus. Monachium.

Kurek H., 1987: Przełączanie kodu językowego, czyli socjolingwistyczne aspekty wzajemnego oddziaływania języka literackiego i dialektów. „Język Polski” LXVII, z. 1-2, s. 63-69.

Levshina N., 2015: How to Do Linguistics with R: Data Erploration and Statistical Analysis. Amsterdam-Filadelfia.

MARTI R., 2018: Romansz i Schwizertütsch $w$ Szwajcarii. W: TAмвоR J., red.: Polonistyka na początku XXI wieku. Diagnozy - koncepcje - perspektywy. T. 4: Pogranicza, mniejszości, regiony. Etnolingwistyka. Katowice, s. 159-174.

Olesch R., 1978: Zur schlesischen Sprachlandschaft. Ihr alter slavischer Anteil. „Zeitschrift für Ostforschung" XXVII, s. 32-43.

Peres-Neto P.R., 1999: How Many Statistical Tests are Too Many? The Problem of Conducting Multiple Inferences Revisited. „Marine Ecology Progress Series” nr 176, s. 303-306.

TAmbor J., 2008: Mowa Górnoślazaków oraz ich świadomość językowa i etniczna. Katowice.

ТАмвов J., 2009: Propozycje kodyfikacji ortograficznej ślaszczyzny. „Socjolingwistyka” XXII-XXIII, S. $83-92$. 
Gerd Hentschel, Istuán Fekete, Jolanta Tambor

Tамвов J., 2013: Ile śląskiego jest $w$ śląskim. W: Hentschel G., red.: Variation und Stabilität in Kontaktvarietäten. Beobachtungen zu gemischten Formen der Rede in Weißrussland, der Ukraine und Schlesien. Oldenburg, s. 1-26.

Wood S., 2006: Generalized Additive Models: An Introduction with R. Florida.

Wood S., 2009: gamm4: Generalized Additive Mired Models Using mgcu and Ime4. $R$ Package [online: http://CRAN.R-project.org/package=gamm4; data dostępu: 2.08.2018].

Gerd Hentschel, Istuán Fekete, Jolanta Tambor

On the Use of German Loan Words in Silesians' Contemporary Ethnolect and Their Linguistic Attitudes (a Working Paper from a Research Project)

Summary

The article presents initial findings from a research project that aims to investigate to what extent German loan words are still in use in Silesian today. Over the centuries, Silesian has adopted far more loan words from German than any other dialect on Polish territory. The project focuses on speakers of Silesian and analyses their so-called subjective frequency of usage of specific Silesian Germanisms in comparison with synonymous words in Standard Polish. Nearly 700 word pairs are tested. The estimates of usage frequency are correlated with the respondents' sociodemographic data and their so-called language attitudes towards Silesian and its position in Silesian-Polish society. The question of how Germanisms are treated is a central issue in the current discussion on the codification of Silesian. 